\title{
Current practices and challenges for modelling past and future land use and land cover changes in mountainous regions
}

\author{
Jacek Kozak ${ }^{1}$ - Urs Gimmi ${ }^{2}$. Thomas Houet ${ }^{3}$ - Janine Bolliger ${ }^{2}$
}

Received: 28 August 2017 / Accepted: 28 August 2017 /Published online: 11 September 2017

(C) The Author(s) 2017. This article is an open access publication

Mountain ecosystems are of particular importance in the context of global change and sustainable development debates (Gleeson et al. 2016), providing several important ecosystem services (Grêt-Regamey et al. 2012), for instance, constituting hotspots for cultural and biophysical diversity and ensuring freshwater supply to neighbouring lowland regions (Debarbieux and Price 2012). Mountain regions have thus high socio-economic value but, at the same time, are often peripheral and less developed due to various physical barriers hampering human activities. In most European mountain regions, this peripheral location facilitates economic decline, followed by depopulation, decrease of traditional human activities (farming, forestry), land abandonment and subsequent re-growth of natural vegetation on abandoned agricultural land (MacDonald et al. 2000; Plieninger et al. 2016; Price et al. 2015). At the same time, new opportunities are being offered by the leisure and tourism industries which sometimes

Jacek Kozak

jacek.kozak@uj.edu.pl

Urs Gimmi

urs.gimmi@wsl.ch

Thomas Houet

thomas.houet@univ-rennes2.fr

Janine Bolliger

janine.bolliger@wsl.ch

1 Institute of Geography and Spatial Management, Jagiellonian University, Gronostajowa 7, 30-387 Kraków, Poland

2 Swiss Federal Institute for Forest, Snow and Landscape Research WSL, Zürcherstrasse 111, CH-8903 Birmensdorf, Switzerland

3 CNRS, Université Rennes 2, LETG UMR 6554 CNRS, Place du recteur Henri Le Moal, 35043 Rennes Cedex, France may attempt to preserve the traditional landscape as an artificial scenery or look for potential benefits of landscape rewilding (Soliva et al. 2010). Rapid landscape changes are particularly pronounced in Eastern Europe, where profound political regime shifts since World War II have triggered many economic, demographic and social pressures (e.g. onset of communist economy in the late 1940 s, and its marketoriented transformation in the 1990s, re-settlements due to boundary changes, rural-urban and post-EU accession migration, depopulation of marginal areas) on landscapes which have not been fully consolidated yet (Jepsen et al. 2015; Pazúr and Bolliger 2017).

An option to disentangle and understand the complexity of land use and land cover change (LULCC) are models for analysing past and projecting future LULCC patterns as a function of changes in social, economic and political conditions. With the increasing availability of digital spatial data with high temporal, spatial and thematic resolutions, LULCC models have become popular multi-functional tools incorporating various mathematical techniques, used in various domains over a range of spatial and temporal scales (Brown et al. 2013; Verburg et al. 2004). These approaches allow assessing the explanatory power of land change drivers, exploring future scenarios and evaluating uncertainty arising from various data sources and modelling techniques (Houet et al. 2015). Although numerical modelling techniques are continuously improved, their fundamental epistemological concern, as in case of any scientific hypothesis, is that they cannot be fully confirmed or demonstrated to provide "the truth". Therefore, the main value of quantitative models is intrinsically heuristic, and knowledge about their limitations is important from the stakeholder, or science-practice perspective (Oreskes et al. 1994). This statement holds true particularly when models are used to explore the future LULCC, even in a predictive or prospective way. 
This special issue explores challenges of the past and future LULCC modelling in mountain regions, addressing the converging interests of two sessions held at the Mountains for the Future Earth Conference in 2015 (Perth, Scotland): "Linking past land use legacies and future land use trajectories in mountain regions" and "Insights and challenges on modelling future LUCC in mountainous regions", with nine selected contributions covering major European mountain ecosystems (the Alps, the Carpathians and the Pyrenees) at the spatial scale ranging from a single mountain valley to entire mountain regions. The focus is on how land use legacies shape contemporary land use decisions and land cover patterns, and how knowledge of the past can be incorporated in models to explore future LULCC and its uncertainty. These questions are of significance to assessments of land systems in mountain regions and of great importance for decision makers and land managers to better define sustainable policies and optimise the provision of ecosystem services.

Six out of nine studies of the special issue reconstruct longterm past land changes (all of them more than 100 years), identify their drivers, and assess their various consequences. Feurdean et al. (2017) explored land use changes on seminatural grasslands in Transylvania, Romania, by linking pollen data to data extracted from a series of topographic maps and satellite images spanning the period 1860-2010. They found out that only $8 \%$ of grasslands had persisted throughout the entire study period and concluded that knowledge about past trajectories should inform the needs of conservation of traditional cultural landscapes in the Carpathian region. Munteanu et al. (2017) looked at land abandonment that had occurred since 1860 across the entire Carpathians and Pannonian Basin, using a set of land use and land cover data retrieved from topographic maps and satellite images. They observed that the land farmed for a longer period of time showed a lower likelihood of abandonment, proving that historical land use patterns influenced contemporary land processes in the region (land use legacy effect). Loran et al. (2017) analysed forest cover expansion in Switzerland between 1850 and 2010, using a reconstruction method based on a series of topographic maps. They focused on time lags, testing whether forest cover changes in a specific time period could be explained by previous or concurrent socio-economic changes. An important finding of this study was that past population changes affected subsequent patterns of forest cover increase in various regions in Switzerland, with time lags of tens of years. Egarter Vigl et al. (2017) attempted a 150-year LULCC reconstruction for the entire Alps to assess changes in the provision of selected ecosystem services, extrapolating findings from a number of case study areas. In their model, they used typical land change trajectories, characteristic for ecoregions defined by biophysical conditions and the initial land use in the mid-nineteenth century. Similarly, Lavorel et al. (2017) considered how long-term LULCC shaped ecosystem services of grasslands, comparing two sites with different trajectories of agricultural development located in the French and Austrian Alps. Following a thematically and spatially detailed reconstruction of grassland use since the nineteenth century, they analysed historical variations of land use patterns and related supply of ecosystem services at different scales. Bolliger et al. (2017) analysed forest cover change in a study region in the Swiss Alps, using a time series of Swiss topographical maps and an ensemble modelling approach to assess the predictive power of various models and to weight explanatory drivers of the observed LULCC. They found out that distance to forest best explained forest cover gains and losses for two modelled time periods (1880-1940 and 1940-2010), and evidenced in this way that the initial forest cover pattern determined patterns of the subsequent forest cover change. However, the models for both periods were independent, thus revealing inherent difficulties of extrapolating LULCC trends from the previous period to the subsequent one.

The remaining three papers of the special issue focus on modelling future land change. Price et al. (2017) used past LULCC to model future forest cover changes by 2060 over large areas in two mountain regions, the Swiss Alps and the Polish Carpathians. They considered three scenarios of land cover changes in both regions relying on identified drivers determining previous forest cover trends and showed that for any scenario, forest cover will increase by $2-3 \%$ in the Swiss Alps and 6-7\% in the Polish Carpathians. The authors referred to land use legacies as one of potentially important factors shaping future land change, a pre-requisite to build the basic future scenario (a trend scenario) and its variations to assess future LULCC. Houet et al. (2017) built scenarios of future LULCC in 2040 and 2100 combining participatory and modelling approaches to assess mountain risks in the municipality of Cauterets in the Pyrenees. To assess the main LULCC trends, they used historical aerial photographs, sharing knowledge resulting from their interpretation with stakeholders. Participatory meetings served then to downscale existing European Union, national or regional scenarios on forestry and agriculture and to define scenario assumptions and model inputs adapted to the local context. Outcomes resulted in narratives and maps of long-term (2100) alternative scenarios which aimed to identify how future land use and land cover affects landslide occurrence. Brunner et al. (2017) assessed future changes in the supply and demand of ecosystem services in the commune Visp located in the Swiss Alps. The uncertainty of modelling was analysed through combining a range of scenarios including changes of climatic and socio-economic drivers as well as societal values. Gains in future ecosystem benefits were found to occur primarily on current agricultural land and were associated with high uncertainty, while losses, on the contrary, were found mostly in remote areas, consistently across the modelled scenarios. 
Both in case of gains and losses of ecosystem benefits, modelling uncertainty relied strongly on the current land use. The results of the study, once transferred to practitioners, may thus convey a message to those who are responsible for land management, providing clues which futures should be avoided, and which options are worth to be followed.

The papers of the special issue used various modelling approaches to identify the importance of environmental and socioeconomic drivers. The modelling approaches ranged from traditional methods, for instance logistic regression (Munteanu et al. 2017), GAMs (Loran et al. 2017) or GLMs (Price et al. 2017), to more novel approaches in land change modelling such as ensemble modelling (Bolliger et al. 2017). Ensemble modelling was proved to be a powerful tool to assess uncertainty of historical forest change and quantify projection robustness by considering a suite of models rather than a single model type. To map LULCC, more complex modelling environments were used, for instance, Dyna-CLUE land use allocation framework (Price et al. 2017), FORESCEM LULCC simulation model (Houet et al. 2017) and integrated modelling system BackES relying on agent-based modelling (Brunner et al. 2017).

A pre-requisite for improving LULCC modelling outcomes is availability of data with high spatial and temporal resolutions (Brown et al. 2013; Verburg et al. 2004). Data issues are clearly evident when modelling of the past LULCC is contrasted with modelling of the future. Reconstructing past LULCC always relies on a strictly limited set of data: topographic maps, orthophotos and land registers (Bolliger et al. 2017; Lavorel et al. 2017; Loran et al. 2017), at times complemented by ancillary data, like pollen records (Feurdean et al. 2017), remote sensing products (Munteanu et al. 2017), interviews or tabular data collected in various surveys and depicting, for instance, socioeconomic driving forces. Relying on map data explains why all studies presented in this volume set the initial moment of the analysis approximately in the mid-nineteenth century - even in Europe, a cartographically privileged part of the world, older maps either do not exist at all or their spatial and thematic accuracies exclude reliable LULCC reconstruction and assessment. In addition, the past land use can be reconstructed only with temporally distant steps, as typically $40-50$ years separate the consecutive topographic surveys. There is also a huge uncertainty related to the completeness and accuracy of map updates - especially in the marginal and less accessible mountain areas, new releases of topographic maps may replicate land use patterns from the previous map editions (Gimmi et al. 2016; Sitko and Troll 2008), decreasing their value for LULCC reconstructions.

Nowadays, data essential for LULCC modelling are increasingly available at high temporal and spatial resolutions, especially through remote sensing (e.g. Hansen et al. 2013). Among future challenges of Geographic Information Science, Goodchild (2010) lists "knowing where everything is, at all times", noting that data abundance is a critically important feature of the present-day development of spatial technologies. LULCC modelling will therefore benefit in near future from quickly growing supplies of high-quality spatial data. Yet the contemporary reliance on remotely sensed products in LULCC modelling (Brown et al. 2013) shifts the focus from more permanent land features typically presented on historic maps to a momentary land cover, provoking questions about the consistency of temporal time series composed of maps and satellite data, and their reliability in assessing land use change (Tropek et al. 2014).

The studies presented in this special issue testify two effects of the past land use on current land patterns, processes and changes. The first effect is a direct consequence of past land use altering biophysical conditions of an area and influencing various processes and contemporary patterns in ecosystems, termed as land use legacies (Foster et al. 2003; Rhemtulla et al. 2009). The other effect is an indirect consequence of past land use decisions creating more or less stable landscape features, like settlement networks or land ownership boundaries that, regardless of their fate, control subsequent land change trajectories. In LULCC modelling, the idea of the past shaping the present and the future is not new in any way, as it is embedded, for instance, in the concepts of land use and land cover trajectories (Levers et al. 2015; Verburg et al. 2010), persistence (Lieskovský and Bürgi 2017) and path-dependence (Brown et al. 2005). The studies of the special issue demonstrate the complexity of connections between land changes and their drivers over a long time frame. Current land use patterns are shown to be a cumulative outcome of past human decisions and actions that reveal variable persistence in the landscape, possess diverse cultural or historical values and, in consequence, need to be taken into account by decision makers in any land management actions.

Contrary to the models of past LULCC which outcomes and relation to the contemporary land use patterns can be easily tested against the ground truth, future LULCC models lack explicit methods allowing even partial confirmation. For a given area and scenario, LULCC models are used to identify where land use change is likely to happen in the future, and what direction the change may have (Vacquie et al. 2015). A scenario represents here an assumption about a future trajectory of various interwoven factors that hypothetically influence and shape LULCC for a given area, and may therefore pick up any subset out of the socioeconomic, political, cultural and biophysical factors that seem relevant. However, even the most detailed land change model assessing the past does not guarantee that the same model assumptions apply for future conditions, as drivers of land change are unlikely to act linearly on the land (Brown et al. 2013; Houet et al. 2016; Paegelow et al. 2013; Verburg et al. 2004). Moreover, several models inherently generate uncertainty as some internal processes are based on randomness. As a result, uncertainty is embedded in future LULCC models (Alexander et al. 2017; Houet et al. 2015). They should not be viewed therefore as tools to predict the future, but rather to extend our capacity to explore 
alternative futures (Dalla-Nora et al. 2014) and to support decisions that lead to a more sustainable land management. The uncertainty and complexity of future LULCC (e.g. Brunner et al. 2017) may affect stakeholder's understanding of research methods and results, influencing efficiency of practical actions related to land management. This is even more critical in the context of mountain research where researchers still regard stakeholders as sources of information rather than fully capable partners in research projects (Gleeson et al. 2016). These shortcomings might be overcome by carefully designed participatory approaches, where stakeholders are part of the research from its very beginning, as seen in Houet et al. (2017). The participatory approaches not only ensure a better understanding of specific local drivers of LULCC, frequently blurred by land use legacies, but also raise awareness of non-scientists about the meaning of the outcomes of LULCC models, increasing chances that they might be considered in future decisions.

Currently, other sources of LULCC modelling uncertainty emerge due to the complexity of land use drivers in the telecoupled world (Liu et al. 2013), as increasing number of distant interactions in land systems influences land changes at any given location, introducing non-linearity and decreasing the LULCC predictability (Meyfroidt et al. 2013). This phenomenon, of lesser significance in mountain areas in the past due to then restricted mobility and relative isolation of mountain societies, nowadays rapidly gains importance. In the near future no mountain area, even the most isolated and remote, will be prone to its effect.

Acknowledgements We would like to thank participants of the Mountains for the Future Earth Conference 2015 in Perth, Scotland, who contributed to this special issue as well as all the reviewers for their helpful contributions in evaluating the submitted papers. Janine Bolliger, Urs Gimmi and Jacek Kozak acknowledge the funding of the project "Forest cover changes in mountainous regions - drivers, trajectories and implications" (FORECOM, PSRP-008/2010), supported by a grant from Switzerland through the Swiss contribution to the enlarged European Union. Thomas Houet acknowledges the Agence Nationale de la Recherche (ANR) for funding the project "Modelling past and future LULCC in the Pyrenees" (MODE RESPYR; ANR 2010 JCJC 180401) that supported the session "Insights and challenges on modelling future LUCC in mountainous regions" at the Mountains for the Future Earth Conference 2015.

Open Access This article is distributed under the terms of the Creative Commons Attribution 4.0 International License (http:// creativecommons.org/licenses/by/4.0/), which permits unrestricted use, distribution, and reproduction in any medium, provided you give appropriate credit to the original author(s) and the source, provide a link to the Creative Commons license, and indicate if changes were made.

\section{References}

Alexander P, Prestele R, Verburg PH, Arneth A, Baranzelli C, Batista e Silva F, Brown C, Butler A, Calvin K, Dendoncker N, Doelman J, Dunford R, Engström K, Eitelberg D, Fujimori S, Harrison PA, Hasegawa T, Havlik P, Holzhauer S, Humpenöder F, Jacobs-
Crisoni C, Jain AK, Krisztin T, Kyle P, Lavalle C, Lenton T, Liu J, Meiyappan P, Popp A, Powell T, Sands RD, Schaldach R, Stehfest E, Steinbuks J, Tabeau A, van Meijl H, Wise MA, Rounsevell MDA (2017) Assessing uncertainties in land cover projections. Glob Change Biol 23(2):767-781. https://doi.org/10.1111/gcb.13447

Bolliger J, Schmatz D, Pazúr R, Ostapowicz K, Psomas A (2017) Reconstructing forest-cover change in the Swiss Alps between 1880 and 2010 using ensemble modelling. Reg Environ Chang. https://doi.org/10.1007/s10113-016-1090-4

Brown DG, Page S, Riolo R, Zellner M, Rand W (2005) Path dependence and the validation of agent-based spatial models of land use. Int $\mathrm{J}$ Geogr Inf Sci 19(2):153-174. https://doi.org/10.1080/ 13658810410001713399

Brown DG, Pontius RG, Lange MD (2013) Opportunities to improve impact, integration, and evaluation of land change models. Curr Opin Environ Sustain 5(5):452-457. https://doi.org/10.1016/j. cosust.2013.07.012

Brunner SH, Huber R, Grêt-Regamey A (2017) Mapping uncertainties in the future provision of ecosystem services in a mountain region in Switzerland. Reg Environ Chang. https://doi.org/10.1007/s10113017-1118-4

Dalla-Nora EL, de Aguiar APD, Lapola DM, Woltjer G (2014) Why have land use change models for the Amazon failed to capture the amount of deforestation over the last decade? Land Use Policy 39:403-411. https://doi.org/10.1016/j.landusepol.2014.02.004

Debarbieux B, Price MF (2012) Mountain regions: a global common good? Mt Res Dev 32(S1):S7-S11. https://doi.org/10.1659/MRDJOURNAL-D-11-00034.S1

Egarter Vigl L, Tasser E, Schirpke U, Tappeiner U (2017) Using land use/ land cover trajectories to uncover ecosystem service patterns across the Alps. Reg Environ Chang. https://doi.org/10.1007/s10113-017$1132-6$

Feurdean A, Munteanu C, Kuemmerle T, Nielsen AB, Hutchinson SM, Ruprecht E, Parr CL, Perşoiu A, Hickler T (2017) Long-term landcover/use change in a traditional farming landscape in Romania inferred from pollen data, historical maps and satellite images. Reg Environ Chang. https://doi.org/10.1007/s10113-016-1063-7

Foster D, Swanson F, Aber J, Burke I, Brokaw N, Tilman D, Knapp A (2003) The importance of land-use legacies to ecology and conservation. BioSci 53(1):77. https://doi.org/10.1641/0006-3568(2003) 053[0077:TIOLUL]2.0.CO;2

Gimmi U, Ginzler C, Müller M, Psomas A (2016) Assessing accuracy of forest cover information on historical maps. Prace Geogr 146:7-18. https://doi.org/10.4467/20833113PG.16.014.5544

Gleeson EH, von Dach SW, Flint CG, Greenwood GB, Price MF, Balsiger J, Nolin A, Vanacker V (2016) Mountains of our future earth: defining priorities for mountain research - a synthesis from the 2015 Perth III Conference. Mt Res Dev 36(4):537-548. https:// doi.org/10.1659/MRD-JOURNAL-D-16-00094.1

Goodchild MF (2010) Twenty years of progress: GIScience in 2010. J Spat Inf Sci 1. https://doi.org/10.5311/JOSIS.2010.1.2

Grêt-Regamey A, Brunner SH, Kienast F (2012) Mountain ecosystem services: who cares? Mt Res Dev 32(S1):S23-S34. https://doi.org/ 10.1659/MRD-JOURNAL-D-10-00115.S1

Hansen MC, Potapov PV, Moore R, Hancher M, Turubanova SA, Tyukavina A, Thau D, Stehman SV, Goetz SJ, Loveland TR, Kommareddy A, Egorov A, Chini L, Justice CO, Townshend JRG (2013) High-resolution global maps of 21st-century forest cover change. Sci 342(6160):850-853. https://doi.org/10.1126/science. 1244693

Houet T, Aguejdad R, Doukari O, Battaia G, Clarke K (2016) Description and validation of a "non path-dependent" model for projecting contrasting urban growth futures. Cybergeo. https://doi.org/10.4000/ cybergeo. 27397

Houet T, Grémont M, Vacquié L, Forget Y, Marriotti A, Puissant A, Bernardie S, Thiery Y, Vandromme R, Grandjean G (2017) 
Downscaling scenarios of future land use and land cover changes using a participatory approach: an application to mountain risk assessment in the Pyrenees (France). Reg Environ Chang. https://doi. org/10.1007/s10113-017-1171-z

Houet T, Vacquié L, Sheeren D (2015) Evaluating the spatial uncertainty of future land abandonment in a mountain valley (Vicdessos, Pyrenees - France): insights from model parameterization and experiments. J Mt Sci 12(5):1095-1112. https://doi.org/10.1007/ s11629-014-3404-7

Jepsen MR, Kuemmerle T, Müller D, Erb K, Verburg PH, Haberl H, Vesterager JP, Andric M, Antrop M, Austrheim G, Björn I, Bondeau A, Bürgi M, Bryson J, Caspar G, Cassar LF, Conrad E, Chromy P, Daugirdas V, van Eetvelde V, Elena-Rosselló R, Gimmi U, Izakovicova Z, Jancák V, Jansson U, Kladnik D, Kozak J, Konkoly-Gyuró E, Krausmann F, Mander Ü, McDonaghy J, Pärn J, Niedertscheider M, Nikodemus O, Ostapowicz K, Pérez-Soba M, Pinto-Correia T, Ribokas G, Rounsevell M, Schistou D, Schmit C, Terkenli TS, Tretvik AM, Trzepacz P, Vadineanu A, Walz A, Zhllima E, Reenberg A (2015) Transitions in European landmanagement regimes between 1800 and 2010. Land Use Policy 49:53-64. https://doi.org/10.1016/j.landusepol.2015.07.003

Lavorel S, Grigulis K, Leitinger G, Kohler M, Schirpke U, Tappeiner U (2017) Historical trajectories in land use pattern and grassland ecosystem services in two European alpine landscapes. Reg Environ Chang. https://doi.org/10.1007/s10113-017-1207-4

Levers C, Müller D, Erb K, Haberl H, Jepsen MR, Metzger MJ, Meyfroidt P, Plieninger T, Plutzar C, Stürck J, Verburg PH, Verkerk PJ, Kuemmerle T (2015) Archetypical patterns and trajectories of land systems in Europe. Reg Environ Chang. https://doi. org/10.1007/s10113-015-0907-x

Lieskovský J, Bürgi M (2017) Persistence in cultural landscapes: a panEuropean analysis. Reg Environ Chang. https://doi.org/10.1007/ s10113-017-1192-7

Liu J, Hull V, Batistella M, DeFries R, Dietz T, Fu F, Hertel TW, Cesar IR, Lambin EF, Li S, Martinelli LA, McConnell WJ, Moran EF, Naylor R, Ouyang Z, Polenske KR, Reenberg A, Rocha de Miranda G, Simmons CS, Verburg PH, Vitousek PM, Zhang F, Zhu C (2013) Framing sustainability in a telecoupled world. Ecol Soc 18(2):art26. https://doi.org/10.5751/ES-05873-180226

Loran C, Munteanu C, Verburg PH, Schmatz DR, Bürgi M, Zimmermann NE (2017) Long-term change in drivers of forest cover expansion: an analysis for Switzerland (1850-2000). Reg Environ Chang. https://oi.org/10.1007/s10113-017-1148-y

MacDonald D, Crabtree J, Wiesinger G, Dax T, Stamou N, Fleury P, Gutierrez Lazpita J, Gibon A (2000) Agricultural abandonment in mountain areas of Europe: environmental consequences and policy response. J Environ Manag 59(1):47-69. https://doi.org/10.1006/ jema.1999.0335

Meyfroidt P, Lambin EF, Hertel TW (2013) Globalization of land use: distant drivers of land change and geographic displacement of land use. Curr Opin Environ Sustain 5(5):438-444. https://doi.org/10. 1016/j.cosust.2013.04.003

Munteanu C, Kuemmerle T, Boltiziar M, Lieskovský J, Mojses M, Kaim D, Konkoly-Gyuró É, Mackovčin P, Müller D, Ostapowicz K,
Radeloff VC (2017) Nineteenth-century land-use legacies affect contemporary land abandonment in the Carpathians. Reg Environ Chang. https://doi.org/10.1007/s10113-016-1097-x

Oreskes N, Shrader-Frechette K, Belitz K (1994) Verification, validation, and confirmation of numerical models in the earth sciences. Sci 263(5147):641-646

Paegelow M, Camacho Olmedo MT, Mas J-F, Houet T, Pontius RG Jr (2013) Land change modelling: moving beyond projections. Int $\mathrm{J}$ Geogr Inf Sci 27(9):1691-1695. https://doi.org/10.1080/13658816. 2013.819104

Pazúr R, Bolliger J (2017) Land changes in Slovakia: past processes and future directions. Appl Geogr 85:163-175. https://doi.org/10.1016/j. apgeog.2017.05.009

Plieninger T, Draux H, Fagerholm N, Bieling C, Bürgi M, Kizos T, Kuemmerle T, Primdahl J, Verburg PH (2016) The driving forces of landscape change in Europe: a systematic review of the evidence. Land Use Policy 57:204-214. https://doi.org/10.1016/j.landusepol. 2016.04.040

Price B, Kaim D, Szwagrzyk M, Ostapowicz K, Kolecka N, Schmatz DR, Wypych A, Kozak J (2017) Legacies, socio-economic and biophysical processes and drivers: the case of future forest cover expansion in the Polish Carpathians and Swiss Alps. Reg Environ Chang. https://doi.org/10.1007/s10113-016-1079-Z

Price B, Kienast F, Seidl I, Ginzler C, Verburg PH, Bolliger J (2015) Future landscapes of Switzerland: risk areas for urbanisation and land abandonment. Appl Geogr 57:32-41. https://doi.org/10.1016/ j.apgeog.2014.12.009

Rhemtulla JM, Mladenoff DJ, Clayton MK (2009) Legacies of historical land use on regional forest composition and structure in Wisconsin, USA (mid-1800s-1930s-2000s). Ecol Appl 19(4):1061-1078. https://doi.org/10.1890/08-1453.1

Sitko I, Troll M (2008) Timberline changes in relation to summer farming in the Western Chornohora (Ukrainian Carpathians). Mt Res Dev 28(3/4):263-271. https://doi.org/10.1659/mrd.0963

Soliva R, Bolliger J, Hunziker M (2010) Differences in preferences towards potential future landscapes in the Swiss Alps. Landsc Res 35(6):671-696. https://doi.org/10.1080/01426397.2010.519436

Tropek R, Sedláček O, Beck J, Keil P, Musilová Z, Šímová I, Storch D (2014) Comment on "High-resolution global maps of 21st-century forest cover change". Sci 344(6187):981-981. https://doi.org/10. 1126/science. 1248753

Vacquie LA, Houet T, Sohl TL, Reker R, Sayler KL (2015) Modelling regional land change scenarios to assess land abandonment and reforestation dynamics in the Pyrenees (France). J Mt Sci 12(4): 905-920. https://doi.org/10.1007/s11629-014-3405-6

Verburg PH, Schot PP, Dijst MJ, Veldkamp A (2004) Land use change modelling: current practice and research priorities. GeoJ 61(4):309324. https://doi.org/10.1007/s10708-004-4946-y

Verburg PH, van Berkel DB, van Doorn AM, van Eupen M, van den Heiligenberg HARM (2010) Trajectories of land use change in Europe: a model-based exploration of rural futures. Landsc Ecol 25(2):217-232. https://doi.org/10.1007/s10980-009-9347-7 